http://dx.doi.org/10.11646/zootaxa.3852.2.6

http://zoobank.org/urn:lsid:zoobank.org:pub:9A5B4990-7171-436B-99D6-43CD639B802A

\title{
First records of Ochrotrichia Mosely, 1934 (Trichoptera: Hydroptilidae) in Northeastern Brazil: Five new species and two new geographical records
}

\author{
WAGNER RAFAEL M. DE SOUZA ${ }^{1}$, ALLAN PAULO MOREIRA SANTOS \& DANIELA M. TAKIYA \\ Laboratório de Entomologia, Departamento de Zoologia, Instituto de Biologia, Universidade Federal do Rio de Janeiro. Caixa Postal \\ 68044, 21941-971 Rio de Janeiro, RJ, Brasil \\ ${ }^{1}$ Corresponding author. E-mail: faelwagner@gmail.com
}

\begin{abstract}
About 170 species have been assigned to the New World genus Ochrotrichia, only two of which were previously recorded from Brazil. Material collected in Bahia and Ceará states represent the first records of this genus from Northeastern Brazil and reveal five new species of Ochrotrichia. These are described and illustrated in this paper: O. caatinga sp. nov. (O. aldama group, from Ceará), O. priapo sp. nov. (O. aldama group, from Bahia); O. limeirai sp. nov. (O. aldama group, from Ceará), $O$. constricta sp. nov. (undetermined group, from Bahia), and O. igrapiuna sp. nov. (O. xena group, from Bahia). Ochrotrichia manuensis Flint \& Bueno-Soria 1999 is firstly recorded from Brazil and O. patulosa (Wasmund \& Holzenthal 2007) is firstly recorded from Northeastern Brazil.
\end{abstract}

Key words: Ochrotrichiinae, taxonomy, Neotropical, microcaddisflies

\section{Introduction}

The Trichoptera family Hydroptilidae, comprising 75 genera and over 2,100 species, is the most diverse of all caddisfly families (Holzenthal et al. 2011; Morse 2014). Six subfamilies are recognised here: Hydroptilinae, Leucotrichiinae, Neotrichiinae, Ochrotrichiinae, Orthotrichiinae, and Stactobiinae, all occurring in the Neotropical Region (as tribes of Hydroptilinae in Holzenthal et al. 2007). Ochrotrichiinae is distributed exclusively in the New World and includes five genera, namely Angrisanoia Ozdikmen, 2008, Metrichia Ross, 1938, Rhyacopsyche Müller, 1879, Ragatrichia Oláh \& Johanson, 2011, and Ochrotrichia Mosely, 1934.

Ochrotrichia was established based on a Jamaican species, O. insularis Mosely 1934, and later some species in Hydroptila Dalman, 1819 and Ithytrichia Eaton, 1873 were transferred to this genus (Flint 1972). Currently, Ochrotrichia comprises over 170 species known throughout North, Central and South America, including the larger islands of the West Indies (Bueno-Soria \& Holzenthal 1998; Morse 2014). Based on adult morphology, Flint (1972) divided the genus into seven species groups: The $O$. xena, $O$. aldama, $O$. arranca, $O$. cruces, $O$. lometa, $O$. tenaga, and $O$. tarsalis groups. To these, Bueno-Soria (2009) added the $O$. blanca group.

In Brazil, the genus is represented by only two species: Ochrotrichia concha Bueno-Soria \& Santiago-Fragoso, 1992, known from Amazonas State (Northern Brazil), and Ochrotrichia patulosa (Wasmund \& Holzenthal, 2007), known from Rio de Janeiro State (Southeastern Brazil). Nevertheless, material in entomological collections from different regions of Brazil indicates that many species remain to be identified and described.

Based on specimens from Bahia and Ceará States, Brazil, we describe and illustrate five new species in this paper: Ochrotrichia caatinga sp. nov., $O$. priapo sp. nov., $O$. limeirai sp. nov., $O$. constricta sp. nov., and $O$. igrapiuna sp. nov. Additionally, we provide the first record of O. manuensis Flint \& Bueno-Soria, 1999 from Brazil (Bahia State) and of O. patulosa in Northeastern Brazil (Ceará State). These collections and the new species represent the first records of the genus Ochrotrichia in Northeastern Brazil. 
Holotype. 1 male, BRAZIL: Bahia: Igrapiúna, Reserva Ecológica Michelin, Mata da Vila 5, 1349'22.9"S, 39¹2'6.5"W, 87 m, 2-4.iv.2012, D.M. Takiya, R. Ale-Rocha, R.A. Carvalho, and M.L Monné cols., Malaise trap (DZRJ).

Paratypes. Same data as holotype, 1 males (DZRJ).

\section{New geographical records}

\section{Ochrotrichia manuensis Flint \& Bueno-Soria, 1999}

\section{Previous known distribution: Peru.}

Material examined. BRAZIL: Bahia: Wenceslau Guimarães, Estação Ecológica Wenceslau Guimarães, afluente do Rio das Almas, 13³5'43.50"S, 3943'11.90"W, 531 m, 3 males, 1-30.v.2011, A.R. Calor col., Malaise trap (MZUFBA).

\section{Ochrotrichia patulosa (Wasmund \& Holzenthal, 2007)}

Previous known distribution: Brazil: Rio de Janeiro: Teresópolis Municipality.

Material examined. BRAZIL: Ceará: Ubajara, Parque Nacional de Ubajara, 0350'31.70"S, 4053'55.5"W, 2 males, 13-17.xi.2012, D.M. Takiya col., Malaise trap (DZRJ).

\section{Acknowledgements}

We are grateful to Coordenação de Aperfeiçoamento de Pessoal de Nível Superior (CAPES) and Conselho Nacional de Desenvolvimento Científico e Tecnológico (CNPq, PROTAX Proc. 562.303/2010-3) for M.Sc. fellowship to WRMS and financial support to DMT, respectively. We also thank Instituto Chico Mendes de Conservação da Biodiversidade (ICMBio) for collecting permits. Field trips to PN Ubajara were possible thanks to funding from the $\mathrm{CNPq} / \mathrm{ICMBio}$ program "Pesquisa em Unidades de Conservação do Bioma Caatinga" coordinated by JA Rafael (INPA, Proc. 551991/2011-9). We thank Dr. A.R. Calor (MZUFBA) for lending valuable specimens from Bahia and all collectors who helped in expeditions to Ceará and Bahia states. WRMS also thanks L. Albuquerque for her help with the manuscript. We also thank Dr. John Morse and two anonymous referees for their comments on this manuscript.

\section{References}

Bueno-Soria, J. (2009) A review of the genus Ochrotrichia Mosely (Trichoptera: Hydroptilidae) from México and Central America. Transactions of the American Entomological Society, 135 (2), 59-160. http://dx.doi.org/10.3157/061.135.0202

Bueno-Soria, J. \& Holzenthal, R.W. (1998) Studies in aquatic insects, XIV: description of eight new species of Ochrotrichia Mosely (Trichoptera: Hydroptilidae), from Costa Rica. Proceedings of the Entomological Society of Washington, 111 (3), 604-612.

Bueno-Soria, J. \& Santiago-Fragosa, S. (1992) Studies in aquatic insects, XI: Seven new species of the genus Ochrotrichia (Ochrotrichia) from South America (Trichoptera: Hydroptilidae). Proceedings of the Entomological Society of Washington, 94 (4), 439-446.

Brown, V.B. (2013) Automating the "Material Examined" section of taxonomy papers to speed up species descriptions. Zootaxa, 3683 (3), 297-299. http://dx.doi.org/10.11646/zootaxa.3683.3.8

Dalman, J.W. (1819) Nagra nya insekt-genera, beskrifina. Kongliga Vetenskap-Akadamiens Handlingar, 40, 117-127.

Dallwitz, M.L., Paine, T.A. \& Zucher, E.J. (1999) User's guide to DELTA Editor. Available from: https://www.deltaintkey.com/ (accessed 20 January 2014)

Eaton, A.E. (1873) On the Hydroptilidae, a family of the Trichoptera. Transition of the Entomological Society of London, 21 (2), 125-150 
http://dx.doi.org/10.1111/j.1365-2311.1873.tb00639.x

Flint, O.S. Jr. (1972) Studies of Neotropical Caddisflies, XIII: The Genus Ochrotrichia from Mexico and Central America (Trichoptera: Hydroptilidae). Smithsonian Contributions to Zoology, 118, 1-28. http://dx.doi.org/10.5479/si.00810282.118

Flint, O.S. Jr. \& Bueno-Soria, J. (1999) Studies on neotropical Caddisflies LVIII: new species of the genus Ochrotrichia Mosely (Trichoptera: Hydroptilidae) from Peru. Proceedings of the Entomological Society of Washington, 101 (4), 729-136.

Frost, S.W. (1957) The Pennsylvania insect light trap. Journal of Economic Entomology, 9, 52-172.

Hadley, A. (2014) CombineZM, Image Stacking Software. Available from: http://www.hadleyweb.pwp.blueyounder.co.uk/ (accessed 20 January 2014).

Holzenthal, R.W., Blahnik, R.J., Prather, A.L. \& Kjer, K.M. (2007) Order Trichoptera Kirby, 1813 (Insecta), Caddisflies, In: Zhang, Z.Q. \& Shear, W.A. (Eds.), Linnaeus Tercentenary: Progress in Invertebrate Taxonomy. Zootaxa, 1668, pp. 639-698.

Holzenthal, R.W., Morse, J.C. \& Kjer, K.M. (2011) Order Trichoptera Kirby, 1813. In: Zhang, Z.Q. (Ed.), Animal Biodiversity: An outline of higher-level classification and survey of taxonomic richness. Zootaxa, 3148, 210-211.

Marshall, J.E. (1979) A review of the genera of the Hydroptilidae (Trichoptera). Bulletin of the British Museum (Natural History) Entomology Series, 39 (3), 135-239.

Morse, J.C. (2014) Trichoptera world checklist. Available from: http://www.clemson.edu/cafls/departamens/esps/database/ trichopt/ (accessed 25 January 2014)

Mosely, M.E. (1934) New exotic Hydroptilidae. Transactions of the Entomological Society of London, 82 (1), $137-163$.

Mosely, M.E. (1937) Mexican Hydroptilidae (Trichoptera). Transactions of the Royal Entomological Society of London, 86 (10), 151-190. http://dx.doi.org/10.1111/j.1365-2311.1937.tb00242.x

Müller, F. (1879) Über Phryganiden (letters to his brother). Zoologischer Anzeiger, 2, 38-40, 180-182, 283-284, $405-407$.

Olah, J. \& Johanson, K.A. (2011) New Neotropical Hydroptilidae (Trichoptera). Annales Historico-Naturales Musei Nationalis Hungarici, 103, 117-255.

Özdikmen, H. (2008) A nomenclatural act for caddis flies (Trichoptera). Munis Entomology \& Zoology, 3 (2), 614-616.

Ross, H.H. (1938) Lectotypes of North American caddisflies in the Museum of Comparative Zoology. Psyche, 45 (10), 1-61. http://dx.doi.org/10.1155/1938/25928

Santos, A.P.M., Dumas, L.L., Jardim, G.A., Silva, A.L.R. \& Nessimian, J.L. (2014) Brazilian Caddisflies: Checklist and bibliography. Available from: https://sites.google.com/site/braziliancaddisflies/ (accessed 21 January 2014)

Wasmund, A.M. \& Holzenthal, R.W. (2007) A revision of Neotropical caddisfly genus Rhyacopsyche, with description of 13 new species (Trichoptera: Hydroptilidae). Zootaxa, 1634, 1-59. 